\title{
Christianity and Tolerance: A Genealogy of European Identity
}

\author{
Daniel Augenstein
}

\begin{abstract}
In the process of European constitutionalisation, the European Union continues to struggle for an identity that can generate widespread support amongst its peoples. Against this background it has been suggested by some that a European identity should embrace the Christian values that underpin Europe's national traditions and cultures. In this paper I shall argue that, instead of relying on a communitarian vision of a 'Christian Europe', a European identity should build on a culture of religious tolerance. A European culture of religious tolerance draws on the enduring of difference and the acknowledgement of persisting and intractable conflict as essential experiences of Europe's Christian past. Thus understood, tolerance lies at the roots of a European identity. At the same time, and through the conditional inclusion of religious diversity in the European Nation-States, a European culture of religious tolerance creates over time new commonalities between Europe's religiously permeated national traditions. Thus understood, tolerance only brings about the conditions for the development of a supranational European identity that amounts to more than (the sum of) its national counterparts.
\end{abstract}




\section{Introduction}

When John Locke wrote his Epistola de Tolerantia in post-Reformation Europe he did not stress the value of religious diversity, nor did he defend religious homogeneity as a necessary backbone for social unity and political legitimacy. Whereas the former must have seemed quite inconceivable to him, the latter was precisely the object of his critique. Locke was committed to the ideal of a religious society deeply rooted in Christian beliefs and values; yet he also realized that in the face of intractably conflicting beliefs over the true path to salvation, any attempt to bring about such a society other than through 'light and evidence' would prove fatal: "it is not the diversity of opinions, which cannot be avoided; but the refusal $^{*}$ of toleration to those that are of different opinions, which might have been granted, that has produced all the bustles and wars, that have been in the Christian world, upon account of religion" (Locke,1991:52). This is a rather defensive claim that may not satisfy those who, four centuries later, have rediscovered Europe's Christian heritage as a potential engine for future European integration. In an era where functional integration has reached its limits, where a national ethos or a European demos is unavailable, and a European public sphere of collective will-formation remains out of sight, the conjuration of a common Christian culture and tradition could, or so it is hoped by some, (re)gain citizens' solidarity for the European project. Thus, or so the argument goes, a European identity should build on the Christian values that underpin Europe's national traditions and cultures. Moreover, the shared commitment to uphold and foster these values should provide a sufficiently thick value-basis to unite the European family of nations.

To be plausible, a genealogy of European identity must be about continuity and transformation: it must commemorate Europe's Christian past and imagine it, in a

\footnotetext{
* The Author is grateful to Maria B. Cahill, Mark Dawson, Jen Hendry, Oliver Schmidtke and Jason R. Young for helpful comments and suggestions.
} 
transformative way, as a common basis for Europe's future. Moreover, it must be about unity and diversity: it must explain the self-constituting of the peoples of Europe in a supranational European order that respects Europe's diverse national traditions and cultures. Against this background, I shall defend the Lockean view and argue that rather than on a communitarian vision of a Christian Europe, a European identity should build on a culture of religious tolerance. Tolerance, the mere 'putting up' with religious diversity, embodies an ambivalent value; as Derrida put it, tolerance "says to the other from its elevated position, I am letting you be, you are not insufferable, I am leaving you a place in my home, but do not forget that this is my home..." (Derrida, 2003:127-28). It is embedded in an area of tension between straightforward rejection and full-hearted acceptance of minoritarian religious worldviews: while preferable to religious exclusion, it appears too negative an engagement with difference when compared to the equal inclusion of religious diversity. I submit that, paradoxically, religious tolerance thus lies at the roots of a European identity and only creates the conditions for its very development. At the outset, I briefly discuss John Locke's defence of religious tolerance in the context of $17^{\text {th }}$ century Christian Europe. I contend that the European societies' capacity to defuse the social destructiveness of religious conflict and to develop an institutional framework for the peaceful coexistence of conflicting religious worldviews is one of the most precious inheritances of the European Enlightenment. It was not a homogeneous Christian culture but an experience of religious conflict and the concomitant development of a culture of religious tolerance that created the conditions for political unity in the early-modern Christian state. Moreover, it was not the attempt to implement religious uniformity but the tolerance of religious diversity that lead to a more appreciative relationship between the Christian denominations in the European Nation-States. In a second step I consider the role of religious tolerance in the European Nation-States, taking the 'headscarf debates' in Germany and France as an example. In the Nation-State, the Christian denominations reached a status 
of mutual acceptance and national belonging displaced religious belief as a means of social integration. At the same time, both religious-communitarian and secular-laic models continue to affirm, albeit in different ways, Christian values as they have shaped their distinctive interpretations of nationhood. This has two major consequences: first, and within the NationState, tolerance is relegated from the level of religious beliefs to the level of merely religiously permeated national traditions; secondly, and among themselves, the European nations disagree about what constitutes their common Christian culture and tradition today. Against this twofold background of a 'Christian Europe' and a 'Europe of the Nation-States' I develop in the final section an argument in favour of a European identity based on religious tolerance. Drawing on Josef Weiler's notion of supranationalism I argue that a European culture of religious tolerance can meet the two challenges for a genealogy of European identity identified above: it remains conscious of Europe's conflictive Christian past yet creates, through the endurance of religious difference, new commonalities between Europe's religiously permeated national traditions. It respects Europe's diverse national identities yet transcends, through the conditional inclusion of religious diversity, the normative horizon of the Nation-State towards a supranational European perspective.

\section{The European heritage of religious tolerance}

Religious tolerance played an important role in the social and political conflicts that divided European societies along religious lines in the $16^{\text {th }}$ and $17^{\text {th }}$ centuries. The civil wars that swept Europe from 1530 to the 1690s were not simply struggles for political power, but also religious conflicts. Religious tolerance initially developed in a context where religious homogeneity was considered indispensable for both social stability and political legitimacy: ecclesiam et imperium esse unum et idem (Lecler, 1965:137). Christian believers and churches encountered each other on the basis of their conflicting claims to religious truth that 
a priori excluded any kind of political compromise. At the same time, religious questions were politicised in their entirety, and any form of religious diversity therefore threatened the political authority of the early modern state. Hence, the decision to have an established church was not merely a question of implementing religious dogma; it was also, importantly, a matter of political stability (Böckenförde, 1991:36-7). And while it was generally assumed that the king should suppress false beliefs, pragmatic considerations led at times to concessions of tolerance as the second-best solution where the enforcement of religious uniformity seemed, for the time being, unachievable. Accordingly, rather than asserting a general right to freedom of religion, tolerance only granted conditional and limited exceptions from the requirement of religious uniformity.

It is against this background that $17^{\text {th }}$ century Protestant thinkers like John Locke (1632-1704) aimed for a more principled justification of religious tolerance. As early as in the Two Tracts on Government (1660), Locke argued that religion had become a major source of civil unrest because Christian leaders and 'the clergy of all sects' had inculcated two erroneous beliefs in both 'princes' and the 'laity': first, that it was a Christian duty to uphold and spread the true way to heaven and, secondly, that this was to be done by force and compulsion. Given the multiplicity of Christian faiths, each of which considered itself orthodox, these beliefs necessarily culminated in the persecution by the government and religious revolts by the people:

\footnotetext{
Hence have the cunning and malice of men taken occasion to pervert the doctrine of peace and charity into a perpetual foundation of war and contention, all those flames that have made such havoc and desolation in Europe, and have not been quenched but with the blood of so many millions, have been at first kindled with coals from the altar, and too much blown with the breath of those that attend the altar, who, forgetting their calling which is to promote peace and meekness (Locke, 1967:160-61).
}

Locke's response in the Epistola de Tolerantia consists of stressing the Christian duty of charity and the social destructiveness of religious persecution. Regarding the former, he emphasises two core moral beliefs as commanded in the Scripture: that God allows each man to worship in the way he sincerely believes to be right and that Christianity should be upheld 
by love and persuasion (Tully, 1990:15). Regarding the latter, Locke argues that because nothing but the essentials of the revelation can be known with certainty, religious diversity is unavoidable and religious differences will prove intractable. Moreover, because "it is only light and evidence that can work a change in men's opinions; and that light can in no manner proceed from corporal sufferings, or any other outward penalties", the state cannot enforce religious uniformity (Locke, 1991:19). Hence, religious persecution is not merely morally wrong because it contradicts the two fundamental Christian beliefs but furthermore irrational in that it cannot succeed in its stated objectives. Under such conditions, Locke concludes, "it is not the diversity of opinion, which cannot be avoided, but the refusal of toleration to those that are of different opinions, which might have been granted, that has produced all the bustles and wars, that have been in the Christian world upon account of religion" (Locke, 1991:52).

Locke's argument against religious persecution issues in a (formal) separation of state and church, grounded in a (material) distinction between "the business of civil government" and "the business of religion". The separation of state and church rests on a now familiar conception of 'formal' or 'reason-based' equality: religious considerations cannot justify political action because the commonwealth is "a society of men constituted only for the procuring, preserving, and advancing of their own civil interests" and "the whole jurisdiction of the magistrate reaches only to these civil concernments" (Locke, 1991:17). The difficulties with such formal equality models are equally familiar, namely that they are not sufficiently sensitive to the consequences of state action. Locke maintains,

[if] such were the state of things, that the interest of the commonwealth required all slaughter of beasts should be forborne for some while, in order to the increasing of the stock of cattle, that had been destroyed by some extraordinary murrain; who sees not that the magistrate, in such a case, may forbid all his subjects to kill any calves for any use whatsoever? Only it is to be observed, that in this case the law is not made about religion, but about political matter; nor is the sacrifice, but the slaughter of calves thereby prohibited (Locke, 1991:37).

However, while the farmer who cannot kill his calf until the stock has been sufficiently increased will merely suffer a temporal economic disadvantage, the religious believer, when 
not engaging in the rituals required by her faith, will risk her salvation. And it is difficult to see why Locke's proposal should seem equally congenial to both of them. This dilemma points to a yet deeper problem with Locke's argument that concerns his material distinction between 'the business of civil government' and 'the business of religion', or between laws made about a 'political matter' and laws made about 'religion'. The boundaries between state and church, Locke maintains, are "fixed and immoveable" because both are "in their original, end, business, and in everything perfectly distinct and infinitely different from each other" (Locke, 1991:26):

It is easy to understand to what end the legislative power ought to be directed, and by what measures regulated, and that is the temporal good and outward prosperity of society. ... And it is also evident what liberty remains to men in reference to their eternal salvation, and that is, that every one should do what he in his conscience is persuaded to be acceptable to the Almighty, on whose good pleasure and acceptance depends his eternal happiness (Locke, 1991:44).

Yet this did not prevent Locke from rubberstamping the use of force against certain doctrines because they constituted, by their very nature, a threat to the civil order of the Commonwealth. This is most obvious in Locke's categorical refusal to tolerate atheists: "Lastly, Those are not at all to be tolerated who deny the being of God. Promises, covenants, and oaths, which are the bonds of human society, can have no hold upon an atheist. The taking-away of God, though but even in thought, dissolves everything” (Locke, 1991:47). It must have been clear to Locke that advocacy of intolerance against atheists was incompatible with his premise about the involuntary nature of religious belief insomuch as the atheist, too, could not simply take up a religious belief by will (Dunn, 1991:179). However, Locke can consistently maintain that people should not be persecuted for their religious (non-) beliefs but on the basis that what they believe amounts to a threat to public order. For Locke, the existence of God and the natural law was a demonstrable truth that lies at the very foundation of morality, indispensable for good government and individual conduct: while the belief in God sustains moral values, the fear of divine punishment restrains rulers from abusing their powers and individual subjects from sedition (Tully, 1993:54). Atheists are not merely 
irrational because they neglect the most obvious truth. They are furthermore immoral because their denial of the existence of God reduces the law of nature to the contradictory interests of individuals who, left to their own fallible devices, have no reason to trust each other and hence no capacity to form a peaceful and stable society. Similarly, having argued that 'Mahometans' should not be excluded from the civil rights of the Commonwealth because of their religion, Locke then maintains that a church

\begin{abstract}
can have no right to be tolerated by the magistrate, which is constituted upon such a bottom, that all those who enter into it, do thereby, ipso facto, deliver themselves up to the protection and service of another prince. ... It is ridiculous for any one to profess himself to be a Mahometan only in religion, but in every thing else a faithful subject to a Christian magistrate, whilst at the same time he acknowledges himself bound to yield blind obedience to the mufti of Constantinople; who himself is entirely obedient to the Ottoman emperor ... (Locke, 1991:46-7).
\end{abstract}

To the extent that the Lockean state is grounded in religious tolerance, it is released from the unconditional nature of obligations to religious truth and becomes subject to the contingencies of politics directed towards the public good. Considered this way, it was the tolerance of religious diversity, rather than the attempt to implement religious homogeneity, that created the conditions for a political unity in the early-modern European states. At the same time, however, Locke's defence of religious tolerance was still embedded in an overarching Christian framework. His notion of state and society remain, as John Dunn has maintained, "shaped and dominated by a picture of the earthly setting of human life as a created order, an order designed and controlled by an omnipotent, omniscient and also, mercifully, benevolent deity: the God of the Christians" (Dunn, 1990:11). And in such a world there was no place for atheists, 'Mahometans' and other sects that had arrived at "such a degree of madness, as that [they] should think fit to teach, for doctrines of religion, such things as manifestly undermine the foundations of society, and are therefore condemned by the judgement of all mankind" (Locke, 1967:45). Hence, religious tolerance in postReformation Europe embodied an ambivalent value. It was embedded in an area of tension between the full-hearted acceptance and the straightforward rejection of minoritarian religious 
worldviews. On the one hand, rather than guaranteeing a general right to freedom of religion, tolerance merely granted conditional and limited concessions of public worship to some of the Christian denominations. And rather than accepting the other as an equal moral partner, it merely required an act of non-reciprocal indulgence towards those considered to be inferior and categorically wrong. Yet on the other hand, tolerance helped to defuse the social destructiveness of religious conflict in early modern Europe. By contesting the justification of religious persecution from religious truth it offered, however, a volatile and imperfect protection against religiously motivated discrimination. By granting conditional and limited exceptions to the norm of religious uniformity, it challenged the association of social and political stability with religious homogeneity and therefore paved the way towards the liberal transformation of the European states. Against this background, then, rather than conjuring a shared Christian culture, a European identity should commemorate the way European Christians have learnt to stabilize the tensions between their conflicting worldviews and to live together in difference. After all, the development of a culture of religious tolerance only created the conditions under which it became possible to discern commonalities between the Christian denominations in the European Nation-States.

\section{National traditions and Christian culture}

The liberal transformation of the European moral and legal-political orders took place gradually. The process of secularisation, the French Revolution and the emergence of the public sphere shaped a new vision of state and society, inaugurating the age of popular sovereignty and human rights. With the concomitant emancipation of the individual from traditional religious communities, and of the political state from the religious order, religion was relegated to the private sphere of society and protected as an individual human or 
fundamental right (Taylor, 2004). As a result of the transition to liberalism, the European states no longer endorse a distinctively religious conception of the good but purport to treat their citizens equally in their religious diversity. Yet this process of transformation through emancipation also posed the question of how to integrate the individual into the secularised society. It is the evolving Nation-State with its emphasis on national identity that fulfilled this task. The Nation-State requires the universal conscription of its citizens who are tied together by virtue of a common history, language, tradition and culture. National belonging displaces religious belief as the new form of social integration. Thus, on the one hand, the linkage between the state and religion is dissolved in favour of a new linkage between the state and the nation. On the other hand, however, and through its appeal to the nation's history and culture, nationhood does not purge society of its now merely implicit religious heritage. The European Nation-States, while no longer defined in distinctively religious terms, continue to affirm Christian values as they have shaped their national cultures and traditions. These national cultures and traditions, in turn, inform the concrete interpretation of fundamental rights so that the recognition of citizens' equal freedom of religion is, to a greater or lesser extent, conditional on and delimited by their acceptance of the nation's Christian heritage.

This is perhaps most obvious in those European states that continue to appeal to their Christian traditions and cultures in processes of political and legal decision-making. During what has become known as the 'crucifix debate' in Germany - that is, the question of whether German school laws can require displaying a cross or crucifix in public school classrooms - a Bavarian administrative court distinguished between the Christian faith (as distinctive religion) and the Christian culture (as merely religiously permeated common culture). On this basis it held that the display of crucifixes in classrooms was not the (in this context illegitimate) expression of a commitment to a particular religious faith but the (legitimate) affirmation of an essential component of the general Christian-occidental tradition and 
common property of its cultural realm (BVerfGE 93, 1 (Kruzifix)). In the subsequent headscarf controversy, a German school board rejected the application of a Muslim teacher unwilling to refrain from wearing her headscarf in school. It held that the wearing of a headscarf in public schools would contravene the principle of state neutrality. Moreover, it considered the headscarf a symbol of cultural disintegration that would endanger social cohesion and school peace. The decision of the school board was upheld by two lower instance administrative courts and the Federal Administrative Court (VG Stuttgart NVWZ 2000, 959, VGH Mannheim NJW 2001, 2899 and BVerwG JZ 2002, 254). The German Federal Constitutional Court, distinguishing between the crucifix as a symbol of the state and the headscarf as an individual statement of the person concerned, held that the latter was in principle covered by the teacher's fundamental right to freedom of religion. Accordingly, it ruled that the headscarf could not be prohibited through an administrative decree but only by means of a parliamentary statute (BVerfGE 108, 282 (Kopftuch Ludin)). By now, many of the German Länder have enacted legislation banning the headscarf while still sanctioning nuns teaching in their traditional costume. The law of Baden-Württemberg, for instance, provides that teachers shall not demonstrate any religious convictions that would contravene the principle of state neutrality. Manifestations of Christian values and traditions, however, are taken to be compatible with this requirement because they fulfil the educational mandate conferred on the state by the German Constitution (Amended Law of April 1 ${ }^{\text {st }}, 2004$ GVB1. Baden-Württemberg 178 (2004)). Similar laws have been passed in Niedersachen, Saarland, Hesse and Bavaria (Langenfeld and Mohsen, 2005:86-94). A recent decision by the Bavarian Constitutional Court confirmed that the preferential treatment of Christian confessions was justified because a Muslim teacher could not credibly convey to her pupils the Christian values and traditions as anchored in the Länder constitutions and the respective school laws (Bayerischer Verfassungsgerichtshof, January 15 2007, Vf. 11-VII-05). While, as Gerstenberg 
puts it, "a distinctive feature of the German approach is the emphasis of freedom of conscience as a principle, another feature of the German approach is the assumption that Christian culture occupies a privileged place in German public life and is, indeed, a postulate of German political identity and social cohesion"(Gerstenberg, 2005:94, 96). Hence, on the one hand, the constitutional protection of freedom of religion requires the state to remain neutral between different religions which, by implication, may justify the ban of headscarves from school; on the other hand, the state is not required to be neutral with regard to different cultural-religious traditions so that it may justifiably discriminate between the Muslim headscarf and the Christian habit. In contrast to Locke's times, it is no longer religious homogeneity but merely a religiously permeated national identity that is considered a necessary prerequisite of social unity and political legitimacy. Accordingly, in the German Nation-State the principle of state neutrality and the constitutional protection of freedom of religion are underpinned by a substantive commitment to a majoritarian Christian culture and tradition. And quite similar to Locke's distinction between the 'business of civil government' and the 'business of religion', it would be naïve to believe that the affirmation of the latter did not impinge on the guarantee of the former. The inclusion of religious minorities is no longer conditional on their religious convictions but on their assimilation to a national tradition and culture that continues to affirm Christian values as they have shaped Germany's distinctive interpretation of nationhood.

European states that adhere to a secular-laic tradition, by contrast, insist on a stricter separation between state and religion. The laic state reacts with institutional blindness to the fact of religious, moral and cultural pluralism. Thus, Article 2 of the French 1958 Constitution states that "France is an indivisible laïque, democratic and social republic. It ensures equality of all citizens before the law with no distinction made on the basis of origin, race or religion. It respects all beliefs." The French principle of lä̈cité that commits French public schools to a 
strictly secular education was challenged in 1989 when three female students insisted on wearing headscarves in class. The headmaster suspended the girls, claiming to apply a wellestablished French rule prohibiting religious symbols in state schools. In contrast to the German Federal Constitutional Court, the Conseil d'État held that the French school authorities were entitled to prohibit the headscarf on a case-by-case basis triggering further debate about the principle of religious neutrality in public education and the status of French national identity (Langenfeld and Mohsen, 2005:93). In 1994, the French parliament eventually passed a law prohibiting the wearing of any signs manifesting a religious affiliation in public schools (Loi no 2004-225 du 15 mars 2004). Unlike the communitarian model, the laic conception of liberal neutrality formally precludes the invocation of Christian values for the justification of public policies and legal decisions. Accordingly, the French ban of religious symbols from public schools does not provide exceptions for expressions of Christian culture and tradition and thus seems to keep with the liberal promise of state neutrality and equal treatment of religious diversity. However, such argument overlooks the fact that the normative ideal of a strictly secular public sphere is itself the expression of a distinctively French national-republican tradition that is infused with Christian values. In an insightful essay, Cécile Laborde distinguishes three different strands of the French laïcité principle that are, in one way or the other, linked to the evolution of the secular nation-state: laïcité as state neutrality qua abstention, that guarantees the inclusion of citizens in the state through the privatisation of religion; laïcité as promotion of individual autonomy providing the foundation for a perfectionist morality; and laïcité as a communitarian ideal that fosters a civic sense of loyalty to a particular historical community. For that purpose, Laborde concludes, "lä̈cité has never really formed part of an autonomous juridical, political or philosophical theory, isolated from concrete historical moments, and has always been intimately linked to the republican project of the entrenchment of the modern liberal society 
born out of the French revolution" (Laborde, 2003:173). This very plausible interpretation of

laïcité as a national tradition sharply contrasts with its claim to neutrality in all three

dimensions identified by Laborde. This is most noticeable as far the perfectionist ideal of individual autonomy and the communitarian emphasis on national loyalty are concerned.

Laïcité's claim to 'neutrality through abstention' is also infused with the French nationalrepublican tradition. Laïcité is a non-neutral principle in a double sense: most obviously, while it claims to treat different religions equally it cannot be neutral with regard to religious and secular doctrines as such. Laïcité even fails on the weaker claim of neutrality between different religions as its distinction between a secular public sphere and a religious private sphere is already the result of a historical process driven by the interrelation between Western Protestantism and secularisation. Hence today there exists an awkward alliance against the headscarf between French left-wing secular Republicanism and right-wing Christian Catholicism:

The Right and the Left can define the prohibition on Islamic headscarves in the classroom as a defence of either French Christian or French secular culture, because the two are not at all mutually exclusive. Current Western Christian religious practice defines that women and men bare their heads in public, non-sacred buildings, and that convention - the absence of a religious marker - has been accepted as a secular practise. But the absence is also a marker, and for other religious traditions with other religious practices, going bareheaded may be seen as an overtly Christian practice, or at the least one in weak disguise, especially if that practice is legislated in a dominantly Christian country (Moruzzi, 1994:664).

The laic interpretation of liberal neutrality proves less neutral than it purports because it privileges, in effect or intention, a secularized Christian culture and tradition. While, as

\section{Modood puts it,}

"for some people, religion is about 'the inner life', or personal conduct or individual salvation [and] for others, it includes communal obligations, a public philosophy and political action ... radical secular political arrangements seem to suit and favour the private kind of religions, but not those that require public action. It is surely a contradiction to require both that the state be neutral about religion and that the state should require religions with public ambitions to give them up". (1998:393)

In short, European Christians will find it much easier to accept the liberal public-private divide with its privatization of religious faith than other religious communities simply because they contributed to its creation in the first place. More importantly, this problem cannot be 
solved by a retreat to formal (reason-based) neutrality because this still leaves open the crucial question as to whether religions should be treated equally in a negative sense (equally restrictive) or in a positive sense (equally unrestrictive). As it has become apparent in the Lockean paradigm, a formal separation of state and church and the exclusion of religious justifications of state action do not suffice to define the place of religion in relation to the 'public good'. As a consequence, and similarly to the German model, the inclusion of religious minorities in the French state is no longer conditional on their religious convictions but on their assimilation to a French national identity that remains infused with Christian values.

With the transition to liberalism, state neutrality and freedom of religion formally forestall discrimination on grounds of religious belief. The liberal state does not merely tolerate its citizens' religious convictions but purports to treat them equally. However, insomuch as liberal neutrality does not require the state to be neutral between absolutely everything, it remains a normatively dependent concept that needs to be interpreted in the light of some non-neutral background assumptions. In the European Nation-States, liberal neutrality is substantiated against the background of national identities that continue to appeal to Christian values as they have shaped their distinctive interpretations of nationhood. Thus both religious-communitarian and secular-laic models privilege, albeit in different ways, a Christian culture as it evolved out of the interplay between religion and secularisation. This has two main consequences: first, and within the Nation-States, the realm of tolerance is relegated from the level of religious beliefs to the level of merely religiously permeated national identities. The inclusion of religious minorities in the Nation-State no longer depends on their religious convictions but on their assimilation to majoritarian national traditions and cultures that remain infused with Christian values. Secondly, and among themselves, the European Nation-States find it hard to agree on what constitutes their common Christian 
culture and tradition today. Neither the religious-communitarian nor the secular-laic national model can serve as a blueprint for a genuine, supra-national European identity.

\section{European supranationalism and religious tolerance}

The peoples of Europe, or so it is maintained in the Preamble of the Draft Treaty establishing a Constitution for Europe, "while remaining proud of their own national identities and history ... are determined to transcend their former divisions and united ever more closely, to forge a common destiny". In this spirit, a European identity must be about continuity and transformation: it must commemorate Europe's conflictive Christian past, but it must also transcend this past in view of creating a common European future. Moreover, a European identity must be about unity and diversity: it must respect Europe's diverse religiously permeated national traditions, but it must also succeed in defining its own distinctive culture capable of holding out against them. Continuity and transformation, unity and diversity: in the light of the foregoing considerations, the conjuration of a 'Christian Europe' seems ill-suited for satisfactorily meeting these challenges. A European identity cannot contend itself with shallow references to the Christian origins of Europe's liberal traditions (taken for granted) or a shared Christian culture as it has evolved in the European Nation-States (taken to be uncontested). Rather, it should build on a European culture of religious tolerance that remains conscious of Europe's conflictive Christian past and respects Europe's diverse national traditions yet transcends the normative horizon of the Nation-State towards a supranational European perspective.

Continuity and transformation: The conjuration of a shared European Christian culture and tradition draws too positive and harmonious a picture of Europe's conflictive Christian past. While the European Union's values of “respect for human dignity, freedom, democracy, equality, the rule of law and respect for human rights" (Article I-2 Draft Constitutional 
Treaty) certainly have Christian roots, they are also the result of an often painful and violent emancipation from these Christian roots as part of the process of secularisation. At the same time, this fails to explain the transformation of Europe's religiously permeated national traditions with regard to creating a genuinely European identity. While both religiouscommunitarian and secular-laic models remain reminiscent of their Christian heritage, they have interpreted this heritage in different ways in the process of formation of the modern state. As the recent controversy about whether to include a reference to Christianity in the European Constitution has shown all too clearly, Europeans find it hard to agree on what constitutes their common Christian culture and tradition today. Cynically put, the greatest common denominator the European nations may agree on is discrimination against nonChristian denominations. Yet apart from deterring the considerable part of Europe's nonChristian populations, such a proposition stands in sharp contrast to the European self-image of open and pluralistic societies. Hence, rather than conjuring a shared Christian culture and tradition, a European identity should commemorate and value the way European Christians have learnt to peacefully live together in difference. It was a culture of religious tolerance that - through the contestation of the linkage between religious homogeneity, social stability and political legitimacy - created the conditions for political unity in the early-modern state and led over time to a more appreciative relationship between the Christian denominations. A European identity based on religious tolerance draws on the endurance of difference and the acknowledgement of persisting and intractable conflicts as essential experiences of Europe's Christian past. Concomitantly, and through the conditional inclusion of religious diversity in the Nation-State, a European identity based on tolerance creates over time new commonalities between Europe's religiously permeated national traditions and cultures.

Unity and diversity: What is at stake when comparing the religious-communitarian and the secular-laic model is not simply a choice between a 'Christian' and a 'secular' Europe 
but also - and intrinsically tied to this - the choice between competing religiously permeated national traditions. Neither of these national traditions can function as a blueprint for a genuine European identity. Rather than developing a supra-national European perspective that respects Europe's diverse national traditions, the choice of either national model would transform the European Union into some form of super-nation state and therewith collapse its often praised 'unity in diversity'. Yet it would, as Weiler has remarked, "be more than ironic if a polity set up as a means to counter the excesses of statism ended up coming round full circle and transforming itself into a (super) state. It would be equally ironic if the ethos which rejected the boundary abuse of the nation-state gave birth to a polity with the same potential for abuse" (Weiler, 1999:341). Weiler's ideal of a supranational European polity, by contrast, dwells on the notion of a "community as a transnational regime" that is "not meant to eliminate the national state but to create a regime which seeks to tame the national interest with a new discipline" (Weiler, 1999:251). Thus supranationalism does not seek to "redraw the actual political boundaries of the polity within the existing nation-state conceptual framework" but to "redefine the very notion of boundaries of the state, between the nation and the state, and within the nation itself" (Weiler, 1999: 250). Similarly to the transition from the Christian to the national state that partly dissolved the linkage between the state and religion in favour of a new linkage between the state and a merely religiously permeated nation, the relationship between the national and the supranational is not one of mutual exclusiveness. Rather, it denotes a process of continuous transformation that partly disentangles the state from the nation, yet retains elements of Europe's national traditions and cultures. In contrast to the former, this continuous transformation no longer rests on an exclusive unity between the state and its people but on a plurality of intersecting national and supranational orders. A European culture of religious tolerance is well-equipped to meet the challenges posed by a supranational identity that assumes a European unity in national diversity. In the European 
Union, religious tolerance retains its ambivalent status between wholehearted acceptance and straightforward rejection, between the inclusion and exclusion of minoritarian religious worldviews. It oscillates between the affirmation and contestation of Europe's religiously permeated national identities that, in turn, inform the concrete interpretation of state neutrality and freedom of religion in the European Nation-States. On the one hand, tolerance remains anchored in Europe's national traditions and cultures. It merely promotes the partial and equivocal inclusion of religious minorities under the condition that they conform to the national Leitkultur [cultural norm]. Thus, the mere endurance of religious difference and the conditional inclusion of religious minorities in the Nation-State functions as an act of national self-affirmation. On the other hand, however, tolerance is situated between and beyond Europe's religiously permeated national traditions and cultures. By claiming exceptions from the cultural norm with regard to a supranational European perspective, tolerance contests the association of national homogeneity with social and political stability that has traditionally underpinned the European Nation-States. In the European Union, religious tolerance builds on the reflexive awareness of individual actors to operate in a supranational space and a corresponding willingness to consider claims for religious inclusion beyond the justificatory context of the Nation-State. Thus understood, religious tolerance challenges Europe's national traditions and cultures as the exclusive reference point for the evaluation of religious claims for recognition in the evolving European polity. Here, the conditional and partial inclusion of religious minorities functions as a contestation of Europe's religiously permeated national frames of reference. A European identity based on a culture of religious tolerance thus simultaneously draws on and transcends Europe's religiously permeated national traditions and cultures. It does not create a European unity by substituting itself for or positing itself above the Nation-States. Rather, it creates a European unity through the common endeavour of guarding against the dangers of communitarianism and religious exclusion within Europe's 
national orders, and by mediating the tensions between these orders. Through this common endeavour, a European culture of religious tolerance transcends the horizon of the NationState and contributes to the development of a supranational European identity that amounts to more than (the sum of) its national counterparts.

What we share is what divides us: A European culture of religious tolerance commemorates the way European Christians have learnt to live together peacefully in difference; thus understood, it lies at the roots of a European identity. Moreover, a European culture of religious tolerance transcends the normative horizon of the Nation-State and therewith creates new commonalities between Europe's religiously permeated national traditions and cultures. As such, it is a precondition for the development of a genuinely supranational European identity. Finally, a European culture of religious tolerance nurtures the hope that the European Union may one day transform into a truly multicultural and pluralistic polity. At the very least it will become increasingly difficult to reject religious claims for recognition on the basis that they conflict with Europe's religiously permeated national traditions and cultures. Those who continue to oppose this normative vision in the name of a 'Christian Europe' should recall that for Christian thinkers like John Locke, religious tolerance was both a Christian moral virtue and a requirement of political prudence: "it is not the diversity of opinions, which cannot be avoided, but the refusal of toleration to those that are of different opinions, which might have been granted, that has produced all the bustles and wars, that have been in the Christian world, upon account of religion". 


\section{Bibliography}

Benedict, Phillip. 1996. Un roi, une loi, deux fois: Parameters for the History of Catholic-Reformed Co-existence in France 1555-1685. In Tolerance and intolerance in the European reformation, edited by O. P. Grell and R. W. Scribner. New York: Cambridge University Press.

Böckenförde, Ernst Wolfgang. 1991. State, society, and liberty: studies in political theory and constitutional law, State, society, and society. New York: Berg.

Derrida, Jacques. 2003. Autoimmunity: Real and symbolic suicides. In Philosophy in a time of terror: dialogues with Jürgen Habermas and Jacques Derrida, edited by J. Habermas, J. Derrida and G. Borradori. Chicago: University of Chicago Press.

Dunn, John. 1990. Interpreting political responsibility: essays 1981-1989. Princeton, N.J.: Princeton University Press.

1991. The Claim to Freedom of Conscience: Freedom of Speech, Freedom of Thought, Freedom of Worship. In From persecution to toleration: the Glorious Revolution and religion in England, edited by O. P. Grell, J. I. Israel and N. Tyacke. Oxford New York: Clarendon Press ;Oxford University Press.

Gerstenberg, Oliver. 2005. Freedom of Conscience in Public Schools. International Journal of Constitutional Law 3 (1):94-106.

Horton, John, Susan Mendus, and John Locke. 1991. John Locke, A letter concerning toleration, in focus, Routledge philosophers in focus series. London; New York: Routledge.

Laborde, Cecile. 2003. Toleration and laïcité. In The culture of toleration in diverse societies : reasonable toleration, edited by C. McKinnon and D. Castiglione. Manchester ; New York: Manchester University Press.

Langefeld, C. , and S. Mohsen. 2005. Germany: The Teacher head scarf case. International Journal of Constitutional Law 3 (1):86-94.

Lecler, John. 1965. Die Geschichte der Religionsfreiheit im Zeitalter der Reformation. Stuttgart: Schwabenverlag.

Locke, John. 1967. Two tracts on government. In Two tracts on government, edited by J. Locke and P. Abrams. London,: Cambridge U.P.

Moruzzi, Norma 1994. A Problem with Headscarves. Contemporary Complexities of Political and Social Identity. Political Theory 22 (4):653-672.

Tully, James. 1990. Toleration, Skepticism and Rights: John Locke on Religious Toleration. In Papers from the 1990 Symposium on Truth and Tolerance, edited by E. J. Furcha. Montreal Faculty of Religious Studies, McGill University Press. 
Review of European and Russian Affairs vol. 4 issue 2/2008 @ RERA 2008 all rights reserved

1993. An approach to political philosophy : Locke in contexts, Ideas in context. Cambridge [England] ; New York, NY, USA: Cambridge University Press.

Weiler, Joseph. 1999. The constitution of Europe: "do the new clothes have an emperor?" and other essays on European integration. Cambridge; New York: Cambridge University Press. 